\title{
PELAKSANAAN DAN PENEGAKKAN HAK ASASI MANUSIA DAN DEMOKRASI DI INDONESIA
}

\author{
Besar \\ Jurusan Psikologi, Fakultas Psikologi, Bina Nusantara University \\ Jl. K.H. Syahdan No. 9, Palmerah, Jakarta Barat 11480 \\ besar@binus.edu
}

\begin{abstract}
The term human right shows that the power or authority a person has the fundamental nature. Number of cases of human rights violations that occur because of lack of understanding of the intrinsic value of every person so easily violate the rights of others. This violation is influenced by some cause. The most influential factors are political, economic, social, cultural and security. This research is examining the existing literature to find out about the importance of knowing human rights in everyday life in society and among students and to know more deeply about its relationship with democracy. The research methodology is explanatory; data used is data skunde namely from books. Based on research results, it can be concluded that the human rights needs to be communicated and implemented within the life of the community and among students. By knowing the obligations of their human rights and the implementation of human rights will be better again.
\end{abstract}

Keywords: human rights, enforcement, democracy

\begin{abstract}
ABSTRAK
Istilah hak asasi menunjukkan bahwa kekuasaan atau wewenang yang dimiliki seseorang tersebut bersifat mendasar atau fundamental. Banyaknya kasus-kasus pelanggaran hak asasi manusia yang terjadi karena kurangnya pemahaman tentang nilai-nilai hakiki yang dimiliki oleh setiap orang sehingga dengan mudah orang melanggar hak orang lain. Pelangaran ini dipengaruhi oleh beberapa sebab atau beberapa factor dan yang dianggap factor yang paling berpengaruh adalah faktor politik, ekonomi, social, budaya dan keamanan. Penelitian ini mengkaji -literatur yang ada untuk mengetahui mengenai pentingnya mengetahui hak asasi manusia dalam kehidupan sehari-hari di masyarakat dan di kalangan mahasiswa serta untuk mengetahui lebih mendalam mengenai hubungannya dengan demokrasi. Metodologi penelitian yang digunakan adalah eksplanatoris; data yang digunakan adalah data sekunder dari buku-buku. Berdasarkan hasil penelitian, dapat disimpulkan bahwa hak asasi manusia perlu dikomunikasikan dan diimplementasikan di dalam kehidupan masyarakat dan di kalangan mahasiswa. Dengan mengatahui hak asasi dan kewajiban asasinya maka pelaksanaan hak asasi manusia akan lebih baik lagi.
\end{abstract}

Kata kunci: hak asasi manusia, penegakkan, demokrasi 


\section{PENDAHULUAN}

Perkembangan dan Pembangunan di Indonesia yang cukup pesat—kalau tidak disebut sebagai perkembangan dan pembangunan yang sangat maju — tentunya mempunyai dampak yang positif atau yang negatif terutama dalam hal hak-hak seseorang baik yang asasi maupun yang derivative, oleh karenanya masyarakat dituntut untuk mengetahui, mampu menjaga dan melaksanakan hak-haknya itu.

Banyak sekali masyarakat yang tidak tahu tentang hak-hak yang menjadi haknya termasuk tidak mengetahui kewajiban-kewajiban yang harus dilaksanakannya, banyak masyarakat yang masih terabaikan hak-haknya sebagai manusia. Sebagai bangsa yang berbudaya dan berdaulat kita harus mampu menjunjung tinggi Hak Asasi Manusia serta menegakkan Hak Asasi Manusia. Dengan banyaknya permasalahan dan pelanggaran terhadap Hak Asasi Manusia maka negara kita masih harus merevitalisasi paradigma tentang Hak Asasi Manusia itu sendiri karena kebanyakan masyarakat indonesia pada umumnya masih kurang sekali terhadap pemahaman tentang hak-hak mereka. Kurangnya pengetahuan, pemahaman dan kesadaran akan Hak Asasi Manusia Itu yang nantinya akan menimbulkan pelanggaran hak asasi manusia.

Hak asasi manusia adalah masalah lokal sekaligus masalah global, yang tidak mungkin diabaikan dengan dalih apapun termasuk di Indonesia. Implementasi hak asasi manusia di setiap negara tidak mungkin sama, meskipun demikian sesungguhnya sifat dan hakikat hak asasi manusia itu sama. Adanya hak asasi manusia menimbulkan konsekwensi adanya kewajiban asasi, di mana keduanya berjalan secara paralel dan merupakan satu kesatuan yang tak dapat dipisahkan. Pengabaian salah satunya akan menimbulkan pelanggaran hak asasi manusia atas hak asasi manusia yang lain. Implementasi hak asasi manusia di Indonesia, meskipun masih banyak kasus pelanggaran hak asasi manusia dari yang ringan sampai yang berat dan belum kondusifnya mekanisme penyelesaiannya, tetapi secara umum baik menyangkut perkembangan dan penegakkannya mulai menampakkan tandatanda kemajuan pada akhir-akhir ini. Hal ini terlihat dengan adanya regulasi hukum Hak Asasi Manusia melalui peraturan perundang-undangan serta dibentuknya Pengadilan Hak Asasi Manusia dalam upaya menyelesaikan berbagai kasus pelanggaran Hak Asasi Manusia yang terjadi.

Penelitian ini bertujuan untuk mengetahui mengenai pentingnya Hak Asasi Manusia dalam kehidupan sehari-hari dimasyarakat dan dikalangan mahasiswa serta untuk mengetahui lebih mendalam mengenai pelaksanaan dan penegakkan Hak Asasi Manusia di Indonesia. Penelitian ini menggunakan pendekatan yuridis normatif dengan meneliti bahan-bahan maupun data kepustakaan yang berkaitan dengan permasalahan (Soekamto \& Mamudji, 1983). Spesifikasi penelitian ini adalah deskriptif analitis karena bertujuan untuk dapat memberikan gambaran lebih rinci tentang Penegakkan Hak Asasi Manusia di Indonesia. Bahan-bahan berupa data sekunder dikumpulkan dan dianalisis secara kualitatif normatif untuk kemudian disajikan dalam bentuk deskriptif.

Adapun bahan-bahan hukum primernya adalah: (1) Undang-Undang Dasar 1945 dengan amandemen; (2) Tap-Tap MPR RI; (3) Undang-Undang nomor 39 Tahun 1999 tentang Hak Asasi Manusia; (4) Undang-Undang nomor 26 Tahun 2000 tentang Pengadilan Hak Asasi Manusia. Serta bahan hukum sekunder yang berupa makalah, karya-karya ilmiah, buku-buku yang ditulis para ahli dan hasil penelitian serta pemberitaan-pemberitaan.

\section{Permasalahan}

Sudah menjadi hal yang salah kaprah bahwa setiap hak yang ada pada diri manusia dianggapnya sebagai hak asasi. Banyak sekali masyarakat kita yang tidak bisa membedakan mana yang disebut sebagai hak asasi dan mana yang bukan hak asasi. Dari banyaknya kasus-kasus pelanggaran Hak Asasi Manusia yang terjadi di Indonesia, seperti kasus Lapindo yang menganggap 
telah terjadi pelanggaran setidaknya ada lima belas (15) hak yang terlanggar yaitu hak hidup, hak atas rasa aman, hak atas informasi, hak pengembangan diri, hak atas perumahan, hak atas pangan, hak atas kesehatan, hak atas pekerjaan, hak pekerja, hak atas pendidikan, hak berkeluarga dan melanjutkan keturunan, hak atas kesejahteraan, hak atas jaminan sosial, hak-hak pengungsi. Kasus Aceh berkaitan dengan Gerakan Aceh Merdeka, Gerakan Papua Merdeka, Penanganan terhadap orang-orang yang diduga teroris yang langsung ditembak mati, ataupun penanganan terhadap orang-orang yang berkasus dari mulai penyidikan sampai pelaksanaan hukuman yang sering melanggar hak-hak saksi atau tersangka.

Banyak peraturan perundangan yang telah diproduksi oleh para pemimpin bangsa ini namun dalam prakteknya masih sering terjadi pelanggaran dan pelaksanaannya dirasa belum maksimal. Negara yang demokratis dianggap sebagai Negara yang menjunjung tinggi hak asasi manusia. Negaranegara yang umumnya sudah menjadi Negara maju relative melaksanakan hak-hak asasi manusia secara lebih baik. Dari permasalahan tersebut di atas, maka rumusan masalahnya adalah: (1) sejauh manakah masyarakat Indonesia mengetahui tentang hak asasi manusia; (2) bagaimana pelaksanaan dan hak asasi manusia di Indonesia; (3) bagaimana penegakkan hak asasi manusia di Indonesia; (4) apakah kaitan antara hak asasi manusia dengan Demokrasi.

\section{HASIL DAN PEMBAHASAN}

\section{Pengertian Hak Asasi Manusia}

Hak Asasi atau hak dasar adalah hak-hak yang pokok atau dasar yang dimiliki oleh setiap manusia sebagai pembawaan sejak ia lahir, yang sangat berkaitan dengan martabat dan harkat manusia tersebut (Thaib, 1988).

Hak adalah kekuasaan atau wewenang yang dimiliki seseorang atas sesuatu. Istilah hak asasi menunjukkan bahwa kekuasaan atau wewenang yang dimiliki seseorang tersebut bersifat mendasar. Tuntutan-tuntutan hak asasi merupakan kewajiban dasar yang harus dipenuhi karena bersifat fundamental. Segala hak lain (hak yang bukan asasi) atau hak derivative bisa dikatakan sebagai penjabaran dari hak-hak ini. Karena hak asasi bersifat mendasar atau fundamental maka pemenuhannya bersifat imperative, artinya hak-hak itu wajib dipenuhi karena hak-hak ini menunjukkan nilai subjek hak, atau perintah yang harus dilaksanakan.

Menurut Dudi (2009), ada beberapa definisi tentang Hak Asasi Manusia. Pertama, Hak Asasi Manusia adalah hak yang melekat pada diri manusia, tanpa hak-hak ini manusia tidak dapat hidup layak sebagai manusia. Kedua, Hak Asasi Manusia adalah hak yang dimiliki manusia yang telah diperoleh dan dibawanya bersamaan dengan kelahirannya atau kehadirannya di dalam kehidupan masyarakat. Ketiga, Hak Asasi Manusia adalah hak-hak dasar yang dibawa manusia sejak lahir yang melekat pada esensinya sebagai anugerah Tuhan. Keempat, Hak Asasi adalah seperangkat hak yang melekat pada hakikat dan keberadaan manusia sebagai mahluk Tuhan Yang Maha Esa dan merupakan anugerah-Nya yang wajib dihormati, dijunjung tinggi, dan dilindungi oleh Negara, hukum, pemeritahan, dan setiap orang demi kehormatan serta perlindungan harkat dan martabat manusia, seperti tertera dalam Pasal 1 ayat 1 UU no 39 tahun 1999 tentang Hak Asasi Manusia.

Menurut Martenson dalam Muladi (2002), Hak Asasi Manusia mempunyai arti sebagai: those rights which are inherent in our nature and without which we cannot live as human being. Dari pengertian yang diberikan oleh Martenson dalam Muladi (2002), maka Hak Asasi Manusia ini melekat secara alamiah pada diri kita sebagai manusia, yang berarti juga bahwa keberadaan Hak Asasi Manusia ini lahir dengan sendirinya dalam diri setiap manusia dan bukan karena keistimewaan yang diberikan oleh hukum atau undang-undang (Kaligis, 2009). 
Dalam Kitab Undang-Undang Hukum Pidana (walaupun berbeda penafsiran tentang umur janin), menganggap bahwa janin yang masih baru beberapa minggu sudah dilindungi oleh hukum, dalam pengertian bahwa janin tersebut sudah menjadi subjek Hak Asasi Manusia (Kaligis, 2009).

Berdasarkan pengertian-pengertian di atas, maka dapat disimpulkan bahwa yang dimaksud dengan Hak Asasi Manusia adalah kekuasaan atau wewenang moral yang dimiliki seseorang berdasarkan martabatnya sebagai manusia. Kekuasaan atau wewenang tersebut bersifat moral karena kekuasaan atau wewenang atas nilai-nilai tersebut menunjukan kebaikan atau martabat manusia sebagai manusia. Orang yang beragama mengatakan bahwa hak-hak dasar yang melekat dan dimiliki oleh setiap orang tersebut merupakan anugerah Tuhan Yang Maha Esa. Karena hak asasi merupakan pemberian Tuhan, maka setiap manusia memilikinya justru karena dia sebagai manusia, artinya hakhak tersebut menunjukkan harkat dan martabat seseorang sebagai manusia. Manusia menjadi manusia karena ia memiliki nilai-nilai yang menjadi kekhasannya sebagai manusia. Nilai-nilai itu menunjukan kemuliaan manusia. Pelanggaran terhadap hak-hak ini disebut sebagai tidakan yang tidak manusiawi karena nilai-nilai dasar kemanusiaannya tidak dihargai.

Berdasarkan pengertian Hak Asasi Manusia di atas, maka ada beberapa ciri pokok Hak Asasi Manusia yaitu: (1) bahwa hak asasi itu tidak diberikan atau diwariskan melainkan melekat pada martabat kita sebagai manusia; (2) bahwa hak asasi itu berlaku untuk semua orang tanpa memandang jenis kelamin, asal-usul, ras, agama, etnik, dan pandangan politik; (3) bahwa hak asasi itu tidak boleh dilanggar. Tidak seorang pun mempunyai hak untuk membatasi atau melanggar hak orang lain. Orang tetap memiliki hak asasi manusia meskipun sebuah Negara membuat hukum yang tidak melindungi bahkan melanggar hak asasi manusia.

\section{Sifat Hak Asasi Manusia}

Berdasarkan pengertian Hak Asasi Manusia seperti diuraikan diatas, ada beberapa sifat dasar Hak Asasi Manusia. Menurut Dudi (2009), sifat-sifat itu antara lain (1) individual: Hak Asasi Manusia melekat erat pada kemanusiaan seseorang dan bukan kelompok; (2) universal: Hak Asasi Manusia dimiliki oleh setiap orang lepas dari suku,ras, agama, Negara, dan jenis kelamin yang dimiliki seseorang; (3) supralegal: Hak Asasi Manusia tidak tergantung pada Negara, pemerintah, atau undangundang yang mengatur hak-hak ini; (4) kodrati: Hak Asasi Manusia bersumber dari kodrat manusia; (5) kesamaan derajat: kesamaan sebagai ciptaan Tuhan maka harkat dan martabat manusia pun sama.

\section{Lokalitas dan Universalitas Hak Asasi Manusia}

Ada perdebatan sekitar universalitas dan lokalitas Hak Asasi Manusia. Pertanyaan pokoknya adalah apakah Hak Asasi Manusia itu bersifat Universal atau Lokal atau Partikul;ar saja. Hak Asasi Manusia sebetulnya berciri universal sekaligus local. Universal dalam pengertian bahwa Hak Asasi Manusia itu melekat pada harkat dan martabat setiap manusia. Jadi setiap manusia harus diakui hakhaknya. Ini merupakan prinsip universal. Setiap manusia harus diakui dan dihormati hak-hak dasarnya sebagai manusia melalui produk hukum atau undang-undang. Namun perumusan atau penentuan hakhak mana yang termasuk dalam Hak Asasi Manusia tidak bisa dilepaskan dari pengalaman sosiokultural suatu masyarakat atau Negara, dengan kata lain perumusan isi Hak Asasi Manusia dan pelaksanaannya sering tidak bisa dilepaskan dari kondisi social, budaya, politik, atau pengalaman Negara yang bersangkutan.

\section{Sejarah Perkembangan Perjuangan Hak Asasi Manusia}

Latar belakang sejarah Hak Asasi Manusia pada hakikatnya muncul karena inisiatif manusia terhadap harga diri dan martabat sebagai akibat tindakan sewenang-wenang dari penguasa, penjajahan, perbudakan, ketidakadilan, dan kedzaliman. Oleh karena itu, perkembangan perjuangan Hak Asasi 
Manusia sesungguuhnya sangat tergantung pada konteks daerah dan jamannya. Dengan demikian, kendati Hak Asasi Manusia bersifat universal tetapi corak dan hasil perjuangannya dimasing-masing tempat dan waktu memiliki perbedaan antara satu Negara dengan Negara lainnya.

Diawali oleh para filsuf seperti filsuf Yunani, Romawi dan Kristen, Plato telah meletakkan dasar-dasar hukum perlindungan Hak Asasi Manusia yang dianggapnya merupakan kewajiban bagi pemerintah suatu Negara, ketika ia mengatakan bahwa pemerintah harus mengupayakan kepentingan rakyatnya dan menjamin kebebasan warga negaranya (Plato, dalam Rapar, 2001). Menurut Aristoteles, Manusia sejak lahir takluk dibawah Hukum Kodrat: yang rasional menguasai yang irrasional. Oleh karena itu selayaknyalah yang berakal budi itu menguasai yang tidak berakal budi yaitu mereka yang hanya mengandalkan kekuatan fisik belaka (Kaligis, 2009).

Setelah usaha yang dilakukan oleh Plato kemudian Aristoteles dan Augustinus maka muncullah usaha untuk memperjuangkan Hak asasi Manusia seperti: Kodeks Ur-Nammu tahun 2050 SM, Kitab Hammurabi tahun 1780 SM, Silinder Cyrus tahun 6 SM, Edicks of Ashoka tahun 3 SM, Piagam Madinah 622, Magna Charta 1215, Petition of Rights 1628, Habeas Corpus 1679, Bill of Rights 1689, United States Declaration of Independence 1776, Declaration des Droits de L'Homme et du Citoyen 1789, Roosevelt's The four Freedom 1941, dan Universal Declaration of Human Rights 1948.

Perjuangan Hak Asasi Manusia Di Inggris, sudah berlangsung sejak tahun 1215 dengan adanya Magna Charta, yang merupakan cermin dari perjuangan rakyat dan bangsawan bagi pembatasan kekuasaan raja John. Masih di Inggris, ditahun 1628 dikeluarkan pula piagam Petition of Rights yang berisi tentang hak-hak rakyat berikut jaminannya. Hak-hak itu adalah menyangkut pajak dan pungutan istimewa yang harus disertai persetujuan, warga negara tidak boleh dipaksa untuk menerima tentara dirumahnya, serta tidak boleh digunakan hukum perang dalam keadaan damai. Selanjutnya ditahun 1679 muncul pula Habeas Corpus Act yang berisikan tentang pengaturan penahanan seseorang, yang disusul dengan dikeluarkannya Bill of Rights yang merupakan undangundang yang diterima parlemen Inggris dan berisi tentang kebebasan dalam pemilihan anggota parlemen, kebebasan berbicara dan mengeluarkan pendapat, ijin parleman dalam penetapan pajak, undang-undang, dan pembentukan tentara, kebebasan beragama, serta diperbolehkannya parlemen untuk mengubah keputusan raja.

Sementara itu di Perancis, perjuangan pengakuan Hak Asasi Manusia tampak ketika terjadi Revolusi Perancis di tahun 1789 dengan semboyannya yang sangat terkenal yaitu liberte (kebebasan), egalite (persamaan), dan fraternite (persaudaraan). Revolusi yang dipelopori kaum borjuis ini kemudian menghasilkan sebuah naskah berjudul Declaration des Droits de L'homme et du Citoyen (Pernyataan hak-hak asasi manusia dan warga Negara). Pada deklarasi ini dinyatakan bahwa "Hak Asasi Manusia adalah hak alamiah yang dimiliki manusia menurut kodratnya, yang tidak dapat dipisahkan dari hakikatnya dan karena itu bersifat suci”.

Selanjutnya di Amerika Serikat, perjuangan Hak Asasi Manusia terlihat dengan adanya Declaration of Independence, sebuah deklarasi kemerdekaan atas ketertindasan dari kekuasaan Inggris pada tanggal 4 Juli 1776. Deklarasi ini pula yang menempatkan Amerika Serikat sebagai Negara pertama yang menetapkan dan melindungi Hak Asasi Manusia dalam Konstitusinya. Perjuangan ini sesungguhnya dipelopori oleh pemikiran John Locke, yakni tentang hak-hak alamiah seperti hak hidup (life), hak kebebasan (liberty), dan hak milik (property). Di samping itu, muncul seiring dengan terjadinya Perang Dunia ke II, dengan dipelopori oleh FD. Roosevelt dikeluarkan pula Atlantic Charter tahun 1941 yang berisi tentang The Four Freedom (empat macam kebebasan), yakni: freedom of religion (kebebasan untuk beragama), freedom of speech and thougt (kebebasan untuk berbicara dan berpendapat), freedom of fear (kebebasan dari rasa takut), freedom of want (kebebasan dari kemiskinan). 
Pada tanggal 10 Desember 1948 Perserikatan Bangsa-Bangsa (PBB) mengeluarkan sebuah deklarasi, yang kemudian dikenal dengan Uniersal Declaration of Human Rights, yakni pernyataan sedunia tentang Hak- Hak Asasi Manusia. Pada pasal 1 deklarasi ini tertuang pernyataan bahwa "sekalian orang dilahirkan merdeka dan mempunyai martabat dan hak-hak yang sama. Mereka diberi karunia akal budi, dan hendaknya bergaul satu sama lain dalam persaudaraan”. Hak-hak yang diakui di dalam piagam PBB ini adalah: hak untuk berfikir dan mengeluarkan pendapat; hak memiliki sesuatu; hak mendapatkan pendidikan dan pengajaran; hak menganut aliran kepercayaan atau agama; hak untuk hidup; hak untuk kemerdekaan hidup; hak untuk memperoleh nama baik; hak untuk memperoleh pekerjaan.

Deklarasi PBB ini menjadi symbol komitmen dunia internasional pada Hak Asasi Manusia sekaligus sebagai pedoman dan standard minimum yang dicita-citakan umat manusia untuk menciptakan dunia yang lebih baik dan damai. Implikasi ini terlihat dari adanya jaminan disetiap Negara atas Hak Asasi Manusia yang tertuang dalam konstitusinya.

Bertolak dari Universal Declaration of Human Rights, PBB, melalui Majelis Umum PBB, pada tahu 1966 mengakui Convenant on Human Rights dalam hukum Internasional dan diratifikasi oleh Negara-negara anggota PBB. Convenant tersebut antara lain adalah The International on Civil and political Rights (Konvensi tentang hak-hak sipil dan politik), The International Convenant on Economic, Social, and Cultural Rights (Konvensi internasional tentang hak ekonomi, social dan budaya), serta Opsional Protocol yakni adanya kemungkinan seorang warga Negara yang mengadukan pelanggaran Hak Asasi Manusia kepada The Human Rights Commitee PBB setelah melalui upaya pengadilan dinegaranya.

Selanjutnya, muncul pula beberapa deklarasi mengenai Hak Asasi Manusia di dunia seperti (Kaligis, 2009): (1) Declaration on Rights of People to Peace (Deklarasi hak bangsa atas perdamaian) tahun 1984 oleh Negara-negara dunia ketiga; (2) Declaration on the Rights to Development (Deklarasi hak atas pembangunan) tahun 1986 oleh Negara-negara dunia ketiga; (3) African Charter on Human and Peoples, yang sering pula disebut dengan Banjul Charter, oleh Negara-negara Afrika yang tergabung dalam persatuan Afrika (AOU) tahun 1981; (4) Cairo Declaration on Human Rights in Islam oleh Negara-negara yang tergabung dalam Organisasi Konferensi Islam tahun 1990; (5) Bangkok Declaration tahun 1993; (6) Deklarasi Wina tahun 1993 yang merupakan deklarasi universal dari negra-negara yang tergabung dalam Perserikatan Bangsa-Bangsa.

Berdasarkan perkembangannya, dapat dikatakan bahwa terdapat tiga generasi perjuangan Hak Asasi Manusia dimuka bumi ini yaitu: (1) generasi pertama yang memperjuangkan hak-hak sipil dan politik dan umumnya bermula dari Negara-negara di Eropa Barat yang bersifat liberal, seperti hak atas hidup, hak atas kebebasan dan keamanan, hak atas kesamaan, hak atas kebebasan berfikir, hak berkumpul, dan lain-lain; (2) generasi kedua yang memperjuangkan hak ekonomi, social, dan budaya yang umumnya diperjuangkan oleh Negara-negera Eropa Timur yang bersifat sosialis, seperti hak atas pekerjaan, hak atas penghasilan yang layak, hak kesehatan, hak membentuk serikat pekerja, hak atas jaminan social dan lain-lain; (3) generasi ketiga yang memperjuangan tentang hak perdamaian dan pembangunan oleh Negara-negara yang sedang berkembang, terutama asia dan afrika, seperti hak kesederajatan dengan bangsa lain, hak kedamaian, hak untuk merdeka dan lain-lain.

Sekarang ini muncul pula gerakan perjuangan Hak Asasi Manusia yang mengkritik peran pemerintah atau Negara yang sangat dominan dalam proses pembangunan. Hal ini bermula dari adanya pembangunan ekonomi terutama di negera-negara yang sedang berkembang, yang ternyata menimbulkan akibat negative bagi keadilan rakyat. Perkembangan pemikiran perjuangan Hak Asasi Manusia dipelopori oleh Negara-negara asia yang dtahun 1983 menghasilkan Declaration of the Basic Duties of Asian People and Government. 


\section{Hak Asasi Manusia di Indonesia}

\section{Pengakuan Hak Asasi Manusia di Indonesia}

Pengakuan Hak Asasi Manusia di Indonesia telah tercantum dalam Undang-Undang Dasar Negara Republik Indonesia 1945 yang sebenarnya telah lebih dahulu ada dibandingkan dengan Deklarasi PBB (Universal Declaration of Human Rights) tanggal 10 Desember 1948.

Pengakuan hak Hak Asasi Manusia di Indonesia tampak pada:

\section{Dalam Pembukaan Undang-Undang Dasar 1945}

Pada alinea pertama dinyatakan: “...Kemerdekaan itu ialah hak segala bangsa...”, alinea ini menunjukkan pengakuan hak asasi manusia berupa hak kebebasan atau kemerdekaan dari segala bentuk penjajahan atau penindasan. Pada alinea kedua dinyatakan: ”...mengantarkan rakyat Indonesia ke depan pintu gerbang kemerdekaan Negara Indonesia yang merdeka, bersatu, berdaulat, adil dan makmur. Alinea ini menunjukkan adanya pengakuan atas hak asasi di bidang politik berupa kedaulatan dan ekonomi.

Pada alinea ketiga dinyatakan: “Atas berkat rahmat Alloh yang maha Kuasa dan dengan didorongkan oleh keinginan luhur supaya berkehidupan kebangsaan yang bebas...”. Alinea ini menunjukkan adanya pengakuan bahwa kemerdekaan itu berkat anugerah Tuhan Yang Maha kuasa. Pada alinea keempat dinyatakan: “... melindungi segenap bangsa Indonesia dan seluruh tumpah darah Indonesia dan untuk memajukan kesejahteraan umum, mencerdaskan kehidupan bangsa dan ikut melaksanakan ketertiban dunia..”. Alinea ini menunjukkan pengakuan akan hak-hak asasi manusia.

\section{Dalam Pasal-pasal Undang-Undang Dasar 1945}

Pasal-pasal di dalam Undang-Undang Dasar 1945 ini menegaskan tentang Hak Asasi Manusia dalam bidang politik, ekonomi, social, dan budaya. Pasal-pasal tersebut adalah:

\section{Pasal 27}

(1) Segala warga Negara bersamaan kedudukannya di dalam hukum dan pemerintahan dan wajib menjunjung hukum dan pemerintahan itu dengan tidak ada kecualinya.

(2) Tiap-tiap warga Negara berhak atas pekerjaan dan penghidupan yang layak bagi kemanusiaan.

(3) Setiap warga Negara berhak dan wajib ikut serta dalam upaya pembelaan Negara.

Pasal 28A

Setiap orang berhak untuk hidup serta berhak mempertahankan hidup dan kehidupannya.

Pasal 28B

(1) Setiap orang berhak membentuk keluarga dan melanjutkan keturunan melalui perkawinan yang sah.

(2) Setiap anak berhak atas kelangsungan hidup, tumbuh dan berkembang serta berhak atas perlindungan dari kekerasan dan diskriminasi.

Pasal 28C

(1) Setiap orang berhak mengembangkan diri melalui pemenuhan kebutuhan dasarnya, berhak mendapat pendidikan dan memperoleh manfaat dari ilmu pengetahuan dan teknologi, seni dan budaya, demi meningkatkan kualitas hidupnya dan demi kesejahteraan umat manusia.

(2) Setiap orang berhak untuk memajukan dirinya dalam memperjuangkan haknya secara kolektif untuk membangun masyarakat, bangsa, dan negaranya. 
Pasal 28D

(1) Setiap orang berhak atas pengakuan, jaminan, perlindungan dan kepastian hukum yang adil serta perlakuan yang sama dihadapan hukum.

(2) Setiap orang berhak untuk bekerja serta mendapat imbalan dan perlakuan yang adil dan layak dalam hubungan kerja.

(3) Setiap warga Negara berhak memperoleh kesempatan yang sama dalam pemerintahan.

(4) Setiap orang berhak atas status kewarganegaraan.

Pasal 28E

(1) Setiap orang bebas memeluk agama dan beribadah menurut agamanya, memilih pendidikan dan pengajaran, memilih pekerjaan, memilih kewarganegaraan, memilih tempat tinggal diwilayah Negara dan meninggalkannya serta berhak kembali.

(2) Setiap orang berhak atas kebebasan meyakini kepercayaan, menyatakan pikiran dan sikap sesuai dengan hati nuraninya.

(3) Setiap orang berhak atas kebebasan berserikat, berkumpul, dan mengeluarkan pendapat.

Pasal 28F

Setiap orang berhak untuk berkomunikasi dan memperoleh informasi untuk mengembangkan pribadi dan lingkungan sosialnya, serta berhak untuk mencari, memperoleh, memiliki, menyimpan, mengolah dan menyampaikan informasi dengan menggunakan segala jenis saluran yang tersedia.

Pasal 28G

(1) Setiap orang berhak atas perlindungan diri pribadi, keluarga, kehormatan, martabat, dan harta benda yang di bawah kekuasaannya, serta berhak atas rasa aman dan perlindungan dari ancaman ketakutan untuk berbuat sesuatu atau tidak berbuat sesuatu yang merupakan hak asasi.

(2) Setiap orang berhak untuk bebas dari penyiksaan atau perlakuan yang merendahkan derajat martabat manusia dan berhak memperoleh suaka politik dari Negara lain.

Pasal 28H

(1) Setiap orang berhak hidup sejahtera lahir batin, bertempat tinggal, dan mendapatkan lingkungan hidup yang baik dan sehat serta berhak memperoleh pelayanan kesehatan.

(2) Setiap orang berhak mendapat kemudahan dan perlakuan khusus untuk memperoleh kesempatan dan manfaat yang sama guna mencapai persamaan dan keadilan.

(3) Setiap orang berhak atas jaminan social yang memungkinkan pengembangan dirinya secara utuh sebagai manusia yang bermartabat.

(4) Setiap orang berhak mempunyai hak milik pribadi dan hak milik tersebut tidak boleh diambil alih secara sewenang-wenang oleh siapapun.

Pasal 28I

(1) Hak untuk hidup, hak untuk tidak disiksa, hak kemerdekaan pikiran dan hati nurani, hak beragama, hak untuk tidak diperbudak, hak untuk diakui sebagai pribadi dihadapan hukum, dan hak untuk tidak dituntut atas dasar hukum yang berlaku surut, adalah hak asasi manusia yang tidak dapat dikurangi dalam keadaan apapun.

(2) Setiap orang berhak bebas dari perlakuan yang bersifat diskriminatif atas dasar apapun dan berhak mendapatkan perlindungan terhadap perlakuan bersifat diskriminatif itu.

(3) Identitas budaya dan hak masyarakat tradisional dihormati selaras dengan perkembangan jaman dan peradaban.

(4) Perlindungan, pemajuan, penegakan, dan pemenuhan hak asasi manusia adalah tanggungjawab Negara, terutama pemerintah.

(5) Untuk menegakkan dan melindungi hak asasi manusia sesuai dengan prinsip Negara hukum yang demokratis, maka pelaksanaan hak asasi manusia dijamin, diatur, dan dituangkan dalam bentuk peraturan perundang-undangan. 
Pasal 28J

(1) Setiap orang wajib menghormati hak asasi manusia dalam tertib kehidupan bermasyarakat, berbangsa, dan bernegara.

(2) Dalam menjalankan hak dan kebebasannya, setiap orang wajib tunduk kepada pembatasan yang ditetapkan dengan undang-undang semata-mata untuk menjamin pengakuan serta penghormatan atas hak dan kebebasan orang lain, dan untuk memenuhi tuntutan yang adil sesuai dengan pertimbangan moral, nilai-nilai agama, keamanan, dan ketertiban umum dalam suatu masyarakat demokratis.

\section{Ketetapan Majelis Permusyawaratan Rakyat Republik Indonesia}

Kurang lebih ada 7 Ketetapan Majelis Permusyawaratan Rakyat yang berhasil ditetapkan dalam bentuk Garis-Garis Besar Haluan Negara (GBHN) yang harus dijalankan oleh Presiden. Walaupun dirasa dalam GBHN dari tahun 1973 sampai GBHN 1988 dirasa belun menyentuh hokum dan hak asasi manusia secara mendalam namun unsur-unsur pelaksanaan dan perlindungan hak asasi manusia sudah ada dalam tujuan pembangunan nasional yakni: "Pembangunan Nasional bertujuan untuk mewujudkan suatu masyarakat adil dan makmur materiil dan spiritual berdasarkan Pancasila di dalam wadah Negara kesatuan Republik Indonesia yang merdeka, berdaulat, dan bersatu dalam suasana perikehidupan Bangsa yang aman, tenteram, tertib dan dinamis, serta dalam lingkungan pergaulan dunia yang merdeka, bersahabat, tertib dan damai” (Komisi Hukum Nasional, 2005).

Ketetapan MPR 1998 menugaskan pada pemerintah agar disusunnya undang-undang tentang hak asasi manusia. Berdasarkan ketetapan MPR tersebut maka dibentuklah undang-undang nomor 39 tahun 1999 tentang Hak Asasi Manusia dan Undang-Undang nomor 26 tahun 2000 tentang Pengadilan Hak Asasi Manusia. Hak asasi manusia yang terkandung dalam keketatapan MPR tersebut antara lain: hak untuk hidup, hak berkeluarga dan melanjutkan keturunan, hak keadilan, hak kemerdekaan, hak atas kebebasan informasi, hak keamanan, hak kesejahteraan, hak perlindungan dan pemajuan.

\section{Peraturan Perundang-Undangan}

Undang-undang yang mengatur tentang Hak Asasi Manusia di Indonesia adalah UndangUndang Nomor 39 tahun 1999. Dalam pasal 12 UU nomor 39 tahun 1999 disebutkan bahwa: Setiap orang berhak atas perlindungan bagi pengembangan pribadinya, untuk memperoleh pendidikan, mencerdaskan dirinya, dan meningkatkan kualitas hidupnya agar menjadi manusia yang beriman, bertaqwa, bertanggungjawab, berakhlak mulia, bahagia, dan sejahtera sesuai dengan hak asasi manusia. Secara umum tentang Hak Asasi Manusia yang ditetapkan pada Undang-undang ini adalah: hak untuk hidup; hak untuk berkeluarga; hak untuk mengembangkan diri; hak untuk memperoleh keadilan; hak atas kebebasan pribadi; hak atas rasa aman; hak atas kesejahteraan; hak turut serta dalam pemerintahan; hak wanita; hak anak, orang tua dan usia lanjut.

\section{Penegakkan Hak Asasi Manusia di Indonesia}

Pelaksanaan Hak Asasi Manusia di Indonesia dianggap kurang terlaksana dengan baik. Kasuskasus yang terjadi di Indonesia seperti penanganan Aceh, Timor Timur, Maluku, Poso, Papua, Semanggi dan Tanjung Priok dianggap sebagai pelaksanaan perlindungan Hak Asasi Manusia yang belum berjalan.

Dalam rangka memberikan jaminan perlindungan terhadap Hak Asasi Manusia dan menangani masalah-masalah yang berkaitan dengan penegakkan Hak Asasi Manusia, pemerintah telah melakukan langkah-langkah antara lain: (1) pembentukan Komisi Hak Asasi Manusia (Komnas HAM) berdasarkan Keputusan Presiden nomor 5 tahun 1993 pada tanggal 7 Juni 1993, yang kemudian dikukuhkan lagi melalui undang-undang nomor 39 tahun 1999 tentang Hak Asasi Manusia; (2) 
penetapan Undang-Undang nomor 26 tahun 2000 tentang Pengadilan Hak Asasi Manusia; (3) pembentukan Pengadilan Hak Asasi Manusia Ad Hoc dengan Keputusan Presiden, untuk memeriksa dan memutuskan perkara pelanggaran HAM berat yang terjadi sebelum diundangkannya UndangUndang nomor 26 tahun 2000; (4) pembentukan Komisi Kebenaran dan Rekonsiliaasi sebagai alternative penyelesaian pelanggaran Ham diluar Pengadilan HAM sebagaimana diisyaratkan oleh Undang-Undang tentang HAM; (5) meratifikasi berbagai konvensi internasional tentang Hak Asasi Manusia.

Sementara itu, konvensi yang telah diratifikasi berkaitan dengan penegakkan Hak Asasi Manusia di Indonesia adalah: (1) Konvensi Jenewa tanggal 12 Agustus 1949 (diratifikasi dengan Undang-Undang nomor 59 tahun 1958); (2) Konvensi tentang Hak Politik Kaum Perempuan (diratifikasi dengan Undang-Undang nomor 68 tahun 1958); (3) Konvensi tentang Penghapusan segala bentuk diskriminasi terhadap Perempuan (diratifikasi dengan Undang-Undang nomor 7 tahun 1984); (4) Konvensi tentang Hak Anak ( diratifikasi dengan Undang-Undang nomor 36 tahun 1990); (5) Konvensi tentang Pelarangan, Pengembangan, Produksi, dan Penyimpanan senjata biologis dan beracun serta Pemusnahannya (diratifikasi dengan Keppres nomor 58 tahun 1991); (6) Konvensi Internasional terhadap Apartheid dalam Olahraga (diratifikasi dengan Undang-Undang nomor 48 tahun 1993); (7) Konvensi menentang Penyiksaan dan Perlakuan atau Penghukuman lain yang kejam, tidak manusiawi, atau merendahkan martabat manusia (diratifikasi dengan Undang-Undang nomor 5 tahun 1998); (8) Konvensi Organisasi Buruh Internasional nomor 87 tahun 1998 tentang kebebasan berserikat dan Perlindungan Hak untuk Berorganisasi (diratifikasi dengan Undang-Undang nomor 83 tahun 1998); (9) Konvensi tentang Penghapusan semua bentuk Diskriminasi Rasial (diratifikasi dengan Undang-Undang nomor 29 tahun 1999); (10) Konvensi tentang Penghapusan segala bentuk diskriminasi terhadap perempuan (diratifikasi dengan Undang-Undang nomor 23 tahun 2004 tentang Penghapusan kekerasan dalam rumah Tangga).

\section{Upaya Pencegahan Pelanggaran Hak Asasi Manusia}

Upaya pendekatan keamanan dengan mengedepankan upaya represif menghasilkan stabilitas keamanan yang sangat stabil namun dianggap banyak sekali menimbulkan terjadinya pelanggaran hak asasi manusia, hal ini tidak boleh terulang kembali, untuk itu supremasi hukum dan demokrasi harus ditegakkan, pendekatan hukum dan dialogis harus dikemukakan dalam rangka melibatkan partisipasi masyarakat dalam kehidupan berbangsa dan bernegara. Perlunya lebih memberikan Desentralisasi melalui otonomi daerah dengan penyerahan berbagai kewenangan dari pemerintah pusat kepada pemerintah daerah. Perubahan paradigma dari penguasa yang menguasai dan ingin dilayani menjadi penguasa yang menjadi pelayan masyarakat dengan cara mengadakan perubahan bidang struktural, dan kultural dalam rangka meningkatkan kualitas pelayanan public untuk mencegah terjadinya berbagai bentuk pelanggaran hak asasi manusia. Perlakuan yang sama terhadap kaum perempuan untuk menikmati dan mendapatkan hak yang sama di bidang politik, ekonomi, sosial, budaya, sipil, dan bidang lainnya, mematuhi Konvensi Perempuan sebagaimana yang telah diratifikasi dalam Undang undang No.7 Tahun 1984.

Supremasi hukum harus ditegakkan, sistem peradilan harus berjalan dengan baik dan adil, para pejabat penegak hukum harus memenuhi kewajiban tugas yang dibebankan kepadanya dengan memberikan pelayanan yang baik dan adil kepada masyarakat pencari keadilan, memberikan perlindungan kepada semua orang menghindari tindakan kekerasan yang melawan hukum dalam rangka menegakkan hukum. Perlunya social control dan lembaga politik terhadap dalam upaya penegakan hak asasi manusia yang dilakukan oleh pemerintah.

\section{Hambatan-hambatan dalam Upaya Penegakkan Hak Asasi Manusia}

Hambatan dalam upaya penegakkan Hak Asasi Manusia yang antara lain adalah: (1) kondisi poleksosbud hankam; (2) faktor komunikasi dan informasi yang belum digunakan secara maksimal 
dan benar; (3) faktor kebijakan pemerintah; (4) faktor perangkat perundangan; (5) faktor aparat dan penindakannya.

Dalam kondisi poleksosbudhankam, kondisi perpolitikan di Indonesia yang masih belum menuju ke arah demokratis yang sebenarnya mempunyai andil yang besar terhadap pelanggaran hakhak asasi manusia. Perekonomian yang belum mendukung dan belum sampai pada tingkat masyarakat yang sejahtera, pengangguran dari yang terdidik sampai pengangguran yang tidak terdidik, perbedaan peta berfikir yang ekstrim yang berdasarkan pada suku, agama, ras dan antar golongan, serta faktor keamanan dianggap sebagai pemicu atau penyebab terjadinya pelanggaran hak asasi manusia atau sebagai penghambat utama upaya penegakkan hak asasi manusia.

Dalam faktor komunikasi dan informasi yang belum digunakan secara maksimal dan secara benar, komunikasi dan informasi yang akurat sangat penting, untuk mengambil dan menghasilkan suatu kebijakan yang berkaitan dengan permasalahan hak-hak warga negara termasuk hak asasi manusia. Sementara itu, dalam faktor kebijakan pemerintah, tidak semua penguasa mempunyai kebijakan yang sama tentang pentingnya hak asasi manusia. Sering kali mereka lupa atau bahkan tidak menghiraukan masalah tentang hak-hak masyarakatdalam menentukan kebijakan.

Dalam faktor perangkat perundangan, peraturan perundang-undangan tentang hak asasi manusia di indonesia sudah banyak, namun dirasa masih belum cukup, termasuk yang tercantum di dalam Undang-Undang Dasar 1945 dengan amandemen. Sebagai contoh adalah masalah interpretasi antara pasal $28 \mathrm{~J}$ dengan pasal 28 I tentang hak hidup yang tidak boleh dikurangi. Dalam faktor aparat dan penindakannya (law enforcement), masih banyaknya permasalahan pada birokrasi pemerintahan Indonesia, tingkat pendidikan dan kesejahteraan sebagian aparat yang dinilai masih belum layak, aparat penegak hukum yang mengabaikan prosedur kerja sering membuka peluang terjadinya pelanggaran Hak Asasi Manusia.

\section{Hak Asasi Manusia harus berdampingan dengan Kewajiban Asasi Manusia}

Hak Asasi Manusia harus senantiasa berdampingan dengan Kewajiban Asasi Manusia, keduanya seperti dua sisi dari mata uang yang sama. Kewajiban Asasi manusia adalah kewajibankewajiban dasar yang pokok yang harus dijalankan oleh manusia dalam kehidupan bermasyarakat, seperti kewajiban untuk tunduk pada peraturan perundang-undangan yang berlaku, kewajiban untuk membangun dan mengembangkan kehidupan, kewajiban untuk saling membantu, kewajiban untuk hidup rukun, kewajiban untuk bekerja sehubungan dengan kelangsungan hidupnya (Kartasapoetra, 1978). Dalam pasal 28 J disebutkan: Setiap orang wajib menghormati hak asasi manusia dalam tertib kehidupan bermasyarakat, berbangsa, dan bernegara (ayat 1). Dalam menjalankan hak dan kebebasannya, setiap orang wajib tunduk kepada pembatasan yang ditetapkan dengan undang-undang semata-mata untuk menjamin pengakuan serta penghormatan atas hak dan kebebasan orang lain, dan untuk memenuhi tuntutan yang adil sesuai dengan pertimbangan moral, nilai-nilai agama, keamanan, dan ketertiban umum dalam suatu masyarakat demokratis (ayat 2).

Dari pasal $28 \mathrm{~J}$ tersebut jelas bahwa disamping hak asasi manusia, juga setiap orang wajib menghormati hak asasi orang lain, yang mengandung arti bahwa setiap orang wajib memenuhi kewajiban asasinya. Karena setiap hak asasi melekat kewajiban asasi.

\section{Hak Asasi Manusia dan Demokrasi}

Hak Asasi Manusia dan Demokrasi tidak dapat dipisahkan. Demokrasi yang memperjuangkan hak atas kebebasan menyatakan pendapat, berserikat dan berpartisipasi aktif dalam menentukan penyelenggaraan Negara merupakan bagian dari Hak Asasi Manusia juga. Salah satu ciri pokok Negara yang menghormati Hak Asasi Manusia adalah Negara yang demokratis. Sebaliknya sebuah 
Negara yang demokratis adalah Negara yang menghormati Hak Asasi Manusia. Pelaksanaan supremasi hukum dan demokrasi, pendekatan hukum dan dialogis harus dikedepankan dalam rangka melibatkan partisipasi masyarakat dalam kehidupan berbangsa dan bernegara menuju masyarakat yang demokratis (Muqoddas, Luthan \& Miftahudin, 1992).

\section{PENUTUP}

\section{Simpulan}

Dengan banyaknya kejadian yang mengarah kepada pelanggaran terhadap hak asasi manusia, menunjukkan bahwa manusia Indonesia (masyarakat, penyelenggara negara dan penegak hukum) belum memahami apa arti sebenarnya hak-hak asasinya (termasuk kewajiban-kewajiban asasinya). Selengkap dan sebaik apapun peraturan perundang-undangan yang mengatur Hak Asasi Manusia hanya akan bernilai bila dipraktekkan dalam kehidupan sehari-hari. Adanya peraturan perundangundangan sudah seharusnya dan sewajarnya untuk dilaksanakan dan ditegakkan. Sistem peradilan yang tidak memihak dan menjatuhkan hukuman kepada yang bersalah berdasarkan atas hukum yang benar dan dijalankan sesuai dengan prosedur hukum yang benar. Hak asasi manusia akan bisa berjalan dengan baik kalau setiap warga negara atau setiap manusia menjalankan haknya dengan mengingat kewajiban-kewajibannya. Hak asasi manusia akan berjalan dengan baik apabila setiap manusia menyadari bahwa ada orang lain yang mempunyai hak yang sama dengan dirinya dengan kata lain bahwa hak asasi manusia akan berjalan dengan baik apabila hak asasinya itu dibatasi oleh hak asasi orang lain. Peraturan perundang-undangan adalah sebagai tools of law enforcement bagi penegakkan Hak Asasi Manusia di Indonesia. Hak asasi manusia akan lebih berjalan atau bisa dijalankan dengan lebih baik dalam suasana perikehidupan bangsa yang demokratis, karena negara yang demokratis senantiasa mendasarkan hukum dalam praktek kenegaraannya, senantiasa menghormati hak-hak warga negaranya dan adanya partisipasi warga negara dalam hal pengambilan kebijakan-kebijakan publik.

\section{Saran}

Dari kesimpulan di atas, maka penulis menyarankan agar: (1) pemerintah bersama-sama dengan masyarakyatnya harus senantiasa berusaha untuk meningkatkan kesadaran akan rasa kemanusiaan yang tinggi, sehingga tercipta masyarakat yang selaras, seimbang dalam menjalankan hak-hak serta kewajibannya; (2) pemerintah menciptakan aparatur hukum yang bersih, dan tidak semena-mena dalam menjalankan tugasnya; (3) memberikan sanksi yang tegas bagi pelanggar Hak Asasi Manusia; (4) penanaman nilai-nilai etika dan keagamaan pada semua lapisan masyarakat.

\section{DAFTAR PUSTAKA}

Dudi, C. (2009). Pengantar pendidikan kewarganegaraan. Bandung: Insan Mandiri.

Kaligis, O. C. (2009). Antologi tulisan ilmu hukum: Jilid 4. Bandung: Alumni.

Kartasapoetra, R. G. (1978). Sistematika hukum tata negara. Jakarta: Bina Aksara.

Komisi Hukum Nasional. (2005). Implikasi Amandemen Konstitusi terhadap Perencanaan Pembangunan Hukum.

Majelis Permusyawaratan Rakyat. (1998). Ketetapan Majelis Permusyawaratan Rakyat Republik Indonesia Nomor XVII/MPR/1998. 
Muladi. (2002). Hak asasi manusia, politik, dan sistem peradilan pidana. Semarang: Badan Penerbit Universitas Diponegoro.

Muqoddas, B., Luthan, M. S., \& Miftahudin, M. (1992). Politik pembangunan hukum nasional. Yogyakarta: UII Press.

Rapar, J. H. (2001). Filsafat politik Plato, Aristoteles, Augustinus, Machiaveli. Jakarta: Raja Grafindo Persada.

Republik Indonesia. (1999). Undang-Undang Nomor 39 Tahun 1999 tentang Hak Asasi Manusia.

Soekamto, S., \& Mamudji, S. (1983). Penelitian Hukum Normatif. Jakarta: Rajawali Pers.

Thaib, D. (1988). Pancasila yuridis konstitusional. Yogyakarta: Penerbit Jurusan Hukum Tata Negara, Universitas Islam Indonesia. 